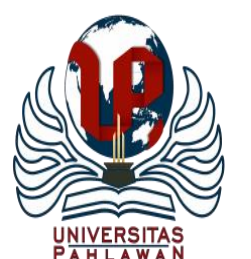

Jurnal Abdidas Volume 2 Nomor 3 Tahun 2021 Halaman 472-482

JURNAL ABDIDAS

http://abdidas.org/index.php/abdidas

\title{
Sosialisasi Penggunaan Kalimat Imperatif Sebagai Strategi Pemasaran UMKM pada Masa Pandemi Covid-19 di Desa Pejeng Gianyar
}

\author{
Dewa Ayu Kadek Claria ${ }^{凶}$ \\ Sastra Inggris, Universitas Warmadewa, Indonesia \\ E-mail: clariadewaayu@gmail.com
}

\begin{abstract}
Abstrak
Kegiatan pengabdian kepada masyarakat ini bertujuan untuk mensosialisasikan penggunaan kalimat imperatif kepada pelaku Usaha Mikro Kecil dan Menengah (UMKM) di Desa Pejeng, Kecamatan Tampaksiring, Kabupaten Gianyar, Provinsi Bali sebagai salah satu bentuk dari strategi pemasaran secara konvensional yang dapat dilakukan di masa pandemi Covid-19. Sosialiasi ini merupakan solusi dari permasalahan yang dihadapi pelaku UMKM yang mengalami hambatan dalam melakukan pemasaran produk karena minimnya dana dan pengetahuan yang dimiliki untuk memecahkan masalah tersebut. Metode komunikasi dua arah digunakan dalam sosialisasi dengan menerapkan teori kesantunan kalimat imperatif yang dikemukakan oleh Rahardi (2005). Hasil pengabdian menunjukkan bahwa pelaku UMKM di Desa Pejeng mampu mengaplikasikan lima jenis kalimat imperatif yang telah diajarkan sebelumnya yang mana penggunaannya bertujuan untuk meningkatkan penjualan produk yang dimiliki pelaku usaha. Kelima jenis kalimat imperatif tersebut terdiri dari kalimat imperatif biasa, kalimat imperatif pemberian izin, kalimat imperatif permintaan, kalimat imperatif suruhan dan kalimat imperatif ajakan. Dari hasil yang diperoleh dapat disimpulkan bahwa pengabdian dalam bentuk sosialisasi sangat efisien dilakukan untuk meningkatkan kemampuan pelaku UMKM dalam memasarkan produk menggunakan kalimat imperatif.
\end{abstract}

Kata kunci: imperatif, UMKM, pemasaran

\section{Abstract}

This community service activity aims to socialize the use of imperative sentences to Small and Medium Enterprise or Usaha Mikro Kecil dan Menengah (UMKM) in Pejeng Village, Tampaksiring District, Gianyar Regency, Bali Province as a form of conventional marketing strategies that can be carried out during the Covid-19 pandemic. This socialization is a solution to the problems faced by the UMKM who experience obstacles in marketing products because of the lack of funds and knowledge they have to solve these problems. Two-way communication method is used in socialization by applying the theory of politeness in imperative sentence proposed by Rahardi (2005). The results of the service show that the UMKM in Pejeng Village are able to apply the five types of imperative sentences that have been taught previously which are used to increase sales of products owned by businessman. The five types of imperative sentences consist of ordinary imperative sentences, permitting imperative sentences, request imperative sentences, imperative orders and invitation imperative sentences. From the results, it can be concluded that this community service is very efficient to increase the ability of the UMKM in marketing their products using imperative sentences.

Keywords: imperative, UMKM, marketing

Copyright (c) 2021 Dewa Ayu Kadek Claria

$\triangle$ Corresponding author

Address : Jl. Terompong No. 24 Denpasar Bali

Email : clariadewaayu@gmail.com

DOI $\quad$ : https://doi.org/10.31004/abdidas.v2i3.300

ISSN 2721- 9224 (Media Cetak)

ISSN 2721- 9216 (Media Online) 
473 Sosialisasi Penggunaan Kalimat Imperatif Sebagai Strategi Pemasaran UMKM pada Masa Pandemi Covid-19 Di Desa Pejeng Gianyar- Dewa Ayu Kadek Claria

DOI: https://doi.org/10.31004/abdidas.v2i3.300

\section{PENDAHULUAN}

Pemasaran merupakan salah satu cara yang digunakan oleh seseorang untuk memperkenalkan produk maupun jasa yang mereka miliki. Pemasaran telah dilakukan dan dikenal masyarakat sejak dahulu dan strategi pemasaran yang dilakukan terus mengalami perkembangan sampai saat ini. Pemasaran yang memiliki tujuan agar suatu produk maupun jasa dapat dikenal oleh masyarakat luas ini memanfaatkan berbagai media untuk mencapai tujuan tersebut. Media yang digunakan pada awalnya bersifat konvensional seperti pemasaran dari mulut ke mulut, penggunaan brosur, selebaran, spanduk maupun papan reklame yang berisikan pesan maupun informasi terkait suatu produk. Pemasaran dalam bentuk lisan telah digunakan sejak lama. Pemasaran dalam bentuk lisan perlu memperhatikan nada suara, intonasi sampai dengan pemilihan kata yang mencerminkan apakah kalimat yang digunakan merupakan suatu penawaran, permohonan dan sebagainya. Sedangkan dalam bentuk tulis, hal yang diperhatikan pada umumnya juga berupa pilihan kata dan juga penggunaan tanda baca titik (.), koma (,), tanya (?) atau seru (!) yang mana penggunaanya dapat mewakili fungsi suatu kalimat apakah dalam bentuk meminta, bertanya, menjabarkan sesuatu atau memerintah seseorang.

Penempatan iklan dalam bentuk tulis yang terdapat pada papan reklame dan spanduk biasanya ditempatkan secara strategis di pusat keramaian dan sebagainya, sehingga mudah dilihat oleh konsumen yang mana hal tersebut berbeda dengan strategi pemasaran secara lisan. Pemasaran mengalami perkembangan sehingga bentuk pemasaran saat ini tidak hanya dalam bentuk media cetak, namun juga dapat melalui media online dalam bentuk iklan baik itu tulis maupun lisan. Iklan merupakan bentuk penyajian dari suatu produk sebagai suatu ide yang dilakukan oleh seseorang baik dalam suatu organisasi maupun perusahaan (Hermawan, 2012). Media pemasaran yang banyak digunakan dalam periklanan adalah dalam bentuk iklan pada televisi, radio, majalah, koran harian, reklame, spanduk, brosur dan juga dengan media internet. Penggunaan media internet sebagai bentuk promosi umumnya dilakukan dengan memanfaatkan media sosial yang saat ini sudah sangat lumrah digunakan seperti penggunaan media Instagram, Facebook dan bahkan Tiktok. Media sosial sendiri dalam dunia teknologi digital memfasilitasi seseorang untuk berhubungan, memproduksi, berinteraksi dan berbagi isi pesan. Pengertian pemasaran terus saja berkembang.

Pemasaran merupakaan interaksi individu dan kelompok pada suatu tempat untuk memperoleh apa yang diinginkan (Kotler, Philip \& Amstrong, 1997). Terlepas dari semua itu, pemasaran baik itu secara lisan maupun cetak pada dasarnya berangkat dari sebuah komunikasi dengan menggunakan kalimat yang mana kalimat itu sendiri memiliki fungsi dalam komunikasi sebagai bentuk interaksi yang dengan mitra tutur (Kasmilawati, Isna \& Agustina, 2019). Apabila dilihat melalui bentuk sintaksinya maka kalimat imperatif dapat berupa kalimat permintaan yang mana mood dari kalimat tersebut berfungsi untuk membantu penyampaian pesan (Hodairiyah, 2019). 
474 Sosialisasi Penggunaan Kalimat Imperatif Sebagai Strategi Pemasaran UMKM pada Masa Pandemi Covid-19 Di Desa Pejeng Gianyar-Dewa Ayu Kadek Claria

DOI: https://doi.org/10.31004/abdidas.v2i3.300

Pada masa pandemi Covid-19 ini, banyak masyarakat kehilangan pekerjaan sehingga berusaha mencoba peruntungan di bidang usaha. Banyaknya pekerja yang dulunya bekerja di sektor pariwisata dan mengalami pemutusan hubungan kerja atau PHK menjadikan keahlian yang mereka miliki sebelumnya dialihkan menjadi berbagai jenis bisnis sehingga banyak bermunculan usaha kecil atau UMKM khususnya di Desa Pejeng Kecamatan Tampaksiring Kabupaten Gianyar Provinsi Bali. Jenis pemasaran yang telah disebutkan sebelumnya dengan memanfaatkan berbagai media pada umumnya membutuhkan dana yang lumayan besar namun mengingat sebagian besar pelaku UMKM di Desa Pejeng memiliki keterbatasan dana dalam mempromosikan produk yang dimiliki, maka satusatunya cara yang dilakukan oleh para pelaku usaha sejauh ini adalah mempromosikan produk yang dimiliki secara konvesional melalui penjualan dalam bentuk pribadi (personal selling).

Keterbatasan dana yang dimiliki juga merupakan dampak dari adanya pandemi Covid19. Tidak jarang para pelaku usaha yang dulunya bekerja sebagai karyawan ini diberhentikan begitu saja tanpa adanya uang pesangon sehingga untuk memulai usaha saja mereka sudah mengalami berbagai kendala. Personal selling merupakan bentuk promosi yang sangat potensial karena dilakukan secara langsung antara produsen dengan konsumen (Sutisna, 2001). Dalam hal ini bentuk tawar menawar maupun penjelasan tentang produk yang dimiliki dapat lebih luwes karena dilakukan secara bertatap muka.
Adanya komunikasi dua arah ini menjadikan penjual dapat melakukan pendekatan maupun memberikan penawaran yang fleksibel (Pitana, 2009). Pelaku UMKM yang pada umumnya baru saja terjun ke dunia usaha ini belum memiliki kemampuan pemasaran dengan memperhatikan penggunaan atau pilihan bahasa sehingga perlu diadakannya sosialisasi terkait pemilihan bahasa yang bagaimana yang nantinya akan mampu menarik perhatian konsumen dengan harapan dapat meningkatkan penjualan.

Bahasa yang digunakan dalam pemasaran dengan menggunakan metode personal selling ini perlu disosialisasikan secara lebih mendalam. Hal tersebut bertujuan agar produk yang ditawarkan mampu memperoleh tanggapan yang baik dari konsumen. Penggunaan bahasa dalam pemasaran terutama dalam bentuk pemasaran yang dilakukan secara langsung oleh produsen kepada konsumen memiliki beberapa aspek penting sehingga dalam pembuatannya diperlukan keterampilan dan ketelitian. Bahasa yang digunakan dalam pemasaran seperti dalam bentuk iklan pada umumnya bersifat persuasif dan mengandung kalimat imperatif atau perintah namun telah dimodifikasi sedemikian rupa sehingga tidak berkesan memerintah namun semata-mata untuk mempengaruhi konsumen agar tertarik pada produk yang ditawarkan. Pemasaran dalam bentuk personal selling umumnya juga menggunakan beberapa kalimat imperatif dan persuasif. Kalimat imperatif merupakan kalimat yang mana pembaca atau pendengar diminta untuk melakukan sesuatu (Chaer, 2015). 
475 Sosialisasi Penggunaan Kalimat Imperatif Sebagai Strategi Pemasaran UMKM pada Masa Pandemi Covid-19 Di Desa Pejeng Gianyar- Dewa Ayu Kadek Claria

DOI: https://doi.org/10.31004/abdidas.v2i3.300

Kalimat perintah yang sering muncul atau digunakan dalam iklan mengandung kata atau tuturan yang secara eksplisit menggambarkan suatu hal yang sifatnya meminta atau menyuruh. Kalimat imperatif dalam bahasa Indonesia terdiri dari lima macam yaitu kalimat imperatif biasa, kalimat imperatif pemberian izin, kalimat imperatif permintaan, kalimat imperatif sentuhan dan kalimat imperatif ajakan (Rahardi, 2005).

Memasarkan produk Usaha Mikro, Kecil dan Menengah (UMKM) memerlukan strategi khusus terutama di masa pandemi Covid-19 ini. Pemilihan kalimat yang baik untuk memasarkan produk UMKM secara konvensional atau secara langsung bertatap muka antara produsen dan konsumen harus mampu menciptakan kesan yang ramah, informatif dan juga menarik. Dalam masa pandemi, metode komunikasi persuasif dapat digunakan untuk meningkatkan motivasi masyarakat dalam berwirausaha (Claria, D.A.K \& Sariani, 2020). Ketika masyarakat mampu untuk merintis atau membangun sebuah UMKM maka yang kemudian menjadi perhatian selanjutnya yaitu pemilihan kalimat dalam proses pemasaran dengan penggunaan media yang terbatas. Dalam hal ini karena adanya keterbatasan biaya dalam promosi maka pemasaran yang dilakukan oleh pelaku usaha hanya sebatas penjualan dari mulut ke mulut yang dilakukan secara langsung dan bertatap muka atau disebut dengan istilah personal selling.

Sehubungan dengan hal tersebut maka strategi pemasaran produk UMKM yang dilakukan oleh masyarakat di Desa Pejeng, Kecamatan Tampaksiring, Kabupaten Gianyar, Provinsi Bali yang mengarah pada sistem pemasaran secara konvesional perlu diperhatikan pemakaian bahasanya dengan cara mengadakan sosialisasi. Seperti telah dijabarkan sebelumnya bahwa banyak metode pemasaran menggunakan kalimat imperatif dalam pengemasannya yang dibuat dengan tujuan menarik perhatian dari konsumen. Hal serupa juga dilakukan oleh pemilik UMKM di Desa Pejeng. Ketertarikan dalam mensosialisasikan penggunaan bahasa dalam pemasaran ini merupakan solusi dari permasalahan yang dialami para pelaku usaha atau UMKM yang baru saja berkecimpung di dunia bisnis. Dari adanya sosialisasi juga dapat dilihat sejauh mana kemampuan para pelaku usaha dalam menggunakan kalimat imperatif dalam berinteraksi dengan konsumen dan bentuk kalimat imperatif apa saja yang digunakan oleh para pelaku usaha yang pada akhirnya dapat menciptakan ketertarikan yang lebih pada masyarakat sebagai maupun konsumen.

Kegiatan ini dilakukan dengan tujuan untuk meningkatkan kemampuan para pelaku UMKM dalam memasarkan produk yang mereka miliki dengan menggunakan kalimat imperatif. Kegiatan yang dilakukan dalam bentuk sosialisasi dipilih karean dianggap paling efisien dalam memberikan atau menerapkan pengetahuna yang baru. Dengan meningkatnya kemampuan pemasaran para pelaku usaha yang berdampak pada meningkatnya penjualan produk, maka hal tersebut akan sangat membantu perekonomian penduduk di Desa Pejeng. 


\section{METODE}

Kegiatan pengabdian ini dilaksanakan dalam bentuk sosialisasi yang dilakukan kepada para pelaku usaha atau UMKM di Desa Pejeng, Kecamatan Tampaksiring, Kabupaten Gianyar, Provinsi Bali. Pelaku usaha yang diberikan sosialisasi terdiri dari 39 orang yang tersebar di Desa Pejeng dengan berbagai jenis usaha baik itu pedagang buah, makanan, kain, baju, pemilik bengkel, toko kelontong dan toko sarana upacara. Pengabdian ini dilakukan selama 1 bulan penuh di bulan April tahun 2021 dengan melibatkan mahasiswa dari Universitas Warmadewa yang berperan ikut turun ke lapangan untuk melakukan sosialisasi.

Dokumentasi setiap kegiatan juga dilakukan untuk melihat sejauh mana perkembangan kemampuan pemasaran para pelaku usaha dalam baik dalam bentuk lisan dan tulisan dapat dipantau. Bentuk kalimat imperatif yang telah digunakan sebelum sosialisasi dalam pemasaran produk UMKM kemudian dilengkapi dengan materimateri baru terutama penggunaan imperatif yang sopan diajarkan melalui sosialisasi. Instrumen yang digunakan dalam pengabdian ini berupa kumpulan kartu data yang telah dilengkapi dengan bentuk-bentuk kalimat imperatif yang dapat digunakan dalam pemasaran produk juga diberikan kepada para pelaku usaha atau UMKM.

Kalima imperatif yang terdapat pada kartu data dibuat dengan menggunakan teori yang dikemukakan oleh Rahardi (2005) tentang kesantunan dalam kalimat imperatif. Rahardi (2005) menyatakan bahwa kalimat imperatif sendiri terdiri dari 5 jenis yaitu kalimat imperatif biasa, kalimat imperatif pemberian izin, kalimat imperatif permintaan, kalimat imperatif suruhan dan kalimat imperatif ajakan. Tahap akhir dari pengabdian kepada masyarakat ini berupa evaluasi terhadap perkembangan kemampuan para pelaku usaha yang dilakukan melalui metode tanya jawab dan kemudian dilanjutkan dengan perumusan kesimpulan yang dilakukan untuk memperoleh jawaban terkait sejauh mana kemampuan para pelaku usaha atau UMKM di Desa Pejeng mengalami peningkatan, sehingga dapat dikatakan mampu dalam menggunakan kalimat imperatif yang tepat dalam mempromosikan produknya.

\section{HASIL DAN PEMBAHASAN}

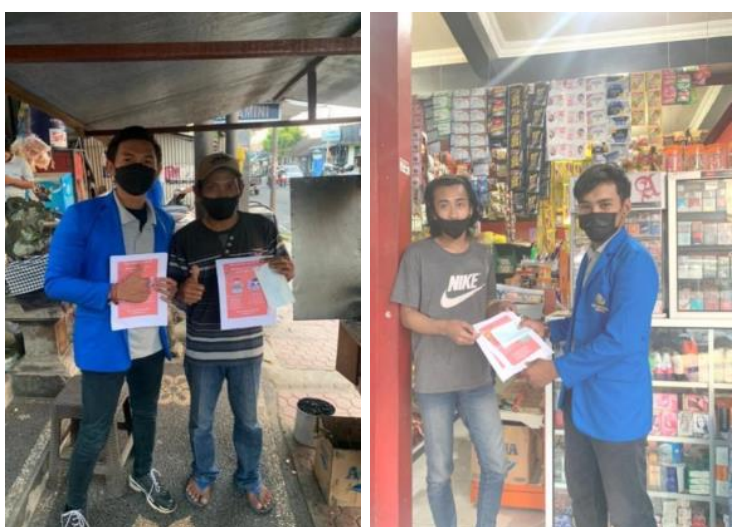

Gambar 1. Penyerahan Materi

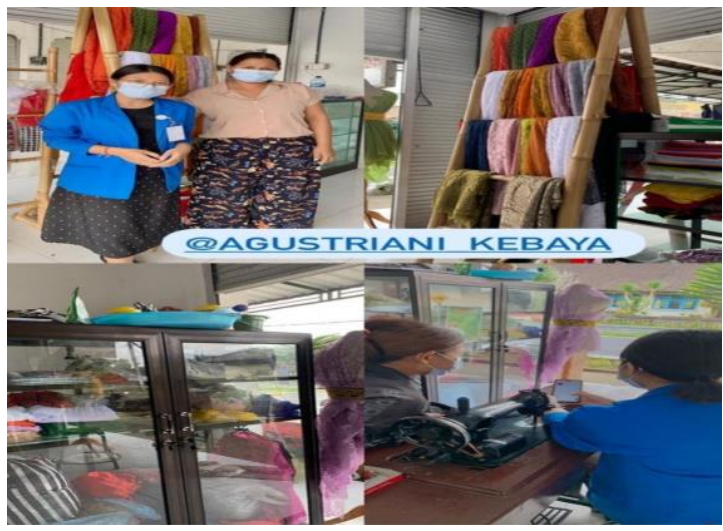

Gambar 2. Sosialisasi Kalimat Imperatif 
477 Sosialisasi Penggunaan Kalimat Imperatif Sebagai Strategi Pemasaran UMKM pada Masa Pandemi Covid-19 Di Desa Pejeng Gianyar-Dewa Ayu Kadek Claria

DOI: https://doi.org/10.31004/abdidas.v2i3.300

Kegiatan sosialisasi dengan mengangkat topik kalimat imperatif yang mencerminkan kesantunan dalam pemasaran ini dilakukan sebagai jawaban dari permasalahan yang dihadapi para pemula dalam dunia usaha atau pelaku UMKM yang baru memulai usahanya akibat harus beralih dari seorang karyawan menjadi wirausaha. Kegiatan sosialisasi dilaksanakan selama sebulan penuh dari hari Senin - Jumat dengan menyasar 5 toko setiap harinya. Kegiatan yang dibantu oleh mahasiswa ini telah mendapat izin dari kepala desa setempat dengan tetap mematuhi program kesehatan yang dicanangkan oleh pemerintah dengan tetap menggunakan masker dan menjaga jarak pada saat dilakukannya sosialisasi. Para pelaku usaha di awal percakapan diminta untuk menjawab pertanyaan awal sebagai bentuk pengukuran kemampuan awal yang kemudian dilanjutkan dengan pemberian kartu data yang disampaikan dan dijelaskan secara rinci bentuk kalimat imperatif yang sebaiknya digunakan.

Berdasarkan hasil pengabdian kepada masyarakat dalam bentuk sosialisasi yang telah dilakukan terhadap pelaku UMKM di Desa Pejeng ini dapat dikatakan bahwa para pelaku usaha telah mampu menggunakan kalimat imperatif yang sopan yang dijabarkan dalam lima jenis kalimat imperatif yang dapat digunakan untuk memasarkan produk di masa pandemi Covid-19. Kelima jenis kalimat tersebut adalah kalimat imperatif biasa, kalimat imperatif pemberian izin, kalimat imperatif permintaan, kalimat imperatif suruhan dan kalimat imperatif ajakan. Kalimat imperatif permintaan ditandai dengan adanya pemarkah atau penanda dalam kalimat yaitu berupa kata tolong, mohon, coba, jangan, harap, sudilah kiranya, diminta dengan hormat, sudikah kiranya, kami mohon agar dan dimohon dengan sangat (Darmawanti, A.A.S, Indriani, M, S \& Astika, 2020). Kalimat imperatif permintaan tersebut juga ditemukan banyak digunakan oleh pengelola UMKM di Desa Pejeng.

\section{a. Kalimat Imperatif Biasa}

Kalimat imperatif biasa merupakan bentuk paling sederhana dari jenis kalimat imperatif atau kalimat perintah yang ada. Kalimat ini umumnya menginginkan lawan bicara untuk melakukan sesuatu. Rahardi (2005: 79) menyatakan bahwa apabila dilihat dari segi intonasi suara, maka kalimat imperatif meskipun hanya imperatif biasa pada umumnya memiliki ciri yaitu berintonasi keras, memiliki kata kerja dasar dan memiliki partikel pengeras -lah sebagai penanda suruhan atau dapat juga memiliki tanda seru (!) pada akhir kalimat. Kalimat imperatif biasa yang digunakan dalam pemasaran produk UMKM dengan pola paling sederhana ini memuat perintah secara langsung dari pelaku usaha terhadap konsumen. Kalimat imperatif ini kemudian digunakan oleh pelaku usaha setelah dengan menggunakan intonasi nada yang lebih rendah sehingga berkesan ramah seperti yang diajarkan pada saat sosialisasi. Kalimat imperatif biasa tersebut dapat dilihat sebagai berikut;

1. Pak Ketut, ayo belanja disini!

2. Beli ini saja Pak! Ikannya masih segar.

Kalimat imperatif biasa yang pertama (1) tersebut dituturkan oleh Bapak Made yang memiliki toko kelontong di Desa Pejeng yang 
478 Sosialisasi Penggunaan Kalimat Imperatif Sebagai Strategi Pemasaran UMKM pada Masa Pandemi Covid-19 Di Desa Pejeng Gianyar- Dewa Ayu Kadek Claria

DOI: https://doi.org/10.31004/abdidas.v2i3.300

kemudian memanggil tetangganya Bapak Ketut untuk mampir berbelanja di tempatnya. Strategi ini digunakan oleh Bapak Made untuk meningkatkan kunjungan dalam bentuk direktif atau percakapan dilakukan secara langsung saat itu juga. Kalimat imperatif biasa yang kedua (2) merupakan potongan percakapan antara Bapak Made dan Bapak Ketut di sela kegiatan pemilihan bahan makanan atau belanjaan yang akan dibeli Pak Ketut pada saat mampir berbelanja ke toko Pak Made. Kedua kalimat imperatif tersebut termasuk dalam imperatif biasa yang lumrah digunakan oleh seseorang ketika memberikan ide atau gagasan kepada seseorang dengan tujuan agar orang tersebut melakukan atau melaksanakan perintah yang dilontarkan dari lawan bicara. Strategi penggunaan kalimat imperatif biasa ini banyak dijumpai digunakan oleh warga Desa yang berkecimpung di bidang UMKM seperti toko kelontong maupun pedagang pasar yang mana penggunaannya dapat dikatakan sangat efektif. Dalam sosialisasi penggunaan kalimat imperatif biasa, hal yang lebih banyak ditekankan adalah penggunaan intonasi pada saat mengucapkan kalimat tersebut sehingga akan membuat kesan ramah. Kalimat imperatif bias ini dapat digunakan oleh pelaku usaha apabila mengenal baik mitra tutur atau konsumen.

\section{b. Kalimat Imperatif Pemberian Izin}

Kalimat imperatif pemberian izin yang mana sesuai dengan yang dijabarkan oleh Ramlan (2005: 81) dapat dilihat dari adanya pemakaian kata silakan. Kalimat imperatif ini juga bertujuan agar lawan bicara dapat melakukan sesuatu seperti yang diinginkan oleh penutur. Kalimat imperatif pemberian izin yang digunakan oleh pelaku usaha di Desa Pejeng dapat dilihat sebagai berikut;

1. Silakan lihat-lihat dulu Bu!

2. Silakan Bapak cek harganya di pengrajin lain! Ini sudah paling murah.

Kalimat nomor 1 menunjukkan bahwa pelaku usaha memberikan izin kepada konsumen untuk melihat terlebih dahulu barang dagangan yang dimiliki sebelum konsumen memutuskan membeli atau tidak. Kalimat suruhan yang mana dalam bentuk pemberian izin ini memiliki kesan yang sopan sehingga sering sekali digunakan oleh pelaku usaha. Kalimat nomor 2 juga merupakan kalimat imperatif pemberian izin yang sering digunakan oleh pelaku usaha kepada konsumen dengan tujuan menyatakan bahwa produk yang mereka miliki adalah yang paling murah sehingga sering kali pelaku usaha menyatakan kalimat "Silahkan Bapak cek harganya di pengrajin lain! Ini sudah paling murah" untuk meyakinkan pengunjung. Teknik pemasaran dengan menggunakan kalimat imperatif pemberian izin ini sangat efektif digunakan sehingga banyak digunakan dalam dunia usaha termasuk para pelaku usaha atau UMKM di Desa Pejeng. Penggunaan kata silakan ini digunakan oleh beberapa pelaku usaha sedari awal dan sebagiannya lagi mampu menggunakan dan menambahkan kata silakan yang berfungsi untuk memperhalus dan memberikan kesan sopan dalam bentuk kalimat imperatif setelah diadakannya sosialisasi. 


\section{c. Kalimat Imperatif Permintaan}

Kalimat imperatif permintaan juga merupakan sebuah kalimat yang mana posisi penutur menginginkan lawan bicara melakukan sesuatu yang merupakan ide atau gagasan yang dimiliki penutur. Dalam hal ini, kalimat imperatif permintaan memiliki kesan yang lebih halus dari kalimat imperatif biasa. Kalimat imperatif permintaan memposisikan penutur sebagai pemilik kepentingan dan demi kepentingannya harus menggunakan kalimat yang santun yaitu dengan menggunakan atau menambahkan kata yang dapat memperhalus kalimat imperatif seperti penggunaan kata tolong, mohon, harap, coba dan sebagainya. Kalimat imperatif permintaan ditemukan digunakan dalam pemasaran produk UMKM oleh pelaku usaha di Desa Pejeng terhadap konsumen dapat dilihat sebagai berikut;

1. Tolong beli satu kain saya ini $\mathrm{Bu}$ !

2. Coba beli buah anggur hitam ini Bu! Dijamin rasanya manis.

Kalimat nomor 1 terjadi di Pasar yang mana ketika pelaku usaha atau pedagang melihat seorang calon pembeli melewati kiosnya, maka mereka dengan spontan berkata "Tolong beli satu kain saya ini Bu!". Kalimat imperatif permintaan ini menggunakan kata tolong untuk membangun kesan sopan yang mana digunakan ketika calon konsumen bukanlah orang yang dikenal. Kalimat nomor 2 bertempat di sebuah toko buah di Desa Pejeng yang menjual beraneka ragam buah. Seorang konsumen membeli buah dan ditawari buah yang lainnya oleh pemilik usaha dengan tujuan meningkatkan penjualan. Pemilik usaha menggunakan kata coba dalam kalimat "Coba beli buah anggur hitam ini Bu! Dijamin rasanya manis". Penggunaan kata coba dalam kalimat imperatif tersebut mengarah pada imperatif permintaan yang mana konsumen diminta untuk mencoba dulu buah yang lainnya dengan harapan konsumen dapat mempertimbangkan hal tersebut yaitu dalam kasus ini yaitu mencoba buah anggur yang kemudian dengan tujuan setelah konsumen mencoba dan memang benar adanya bahwa buah anggur tersebut terasa manis, maka konsumen akan membelinya. Kalimat imperatif permintaan yang digunakan dalam kedua kalimat tersebut sering digunakan oleh pelaku usaha UMKM di Desa Pejeng sebagai strategi dalam penjualan produk yang mereka miliki. Penggunaan kalimat imperatif permintaan juga sering digunakan oleh pelaku UMKM untuk memasarkan produk yang mereka miliki. Setelah dilakukan sosialisasi, para pelaku UMKM dapat menggunakan kalimat imperatif permintaan secara lebih baik.

\section{d. Kalimat Imperatif Suruhan}

Kalimat imperatif suruhan merupakan kalimat yang mana lawan tutur diharapkan melakukan sesuatu oleh penutur dengan menambahkan partikel -lah pada akhir kata. Pelaku usaha di Desa Pejeng juga memakai kalimat imperatif suruhan ini dalam strategi pemasaran produk yang mereka miliki. Kalimat imperatif suruhan tersebut dapat dilihat dalam kalimat yang digunakan oleh pedagang di pasar sebagai berikut;

1. Lihatlah Pak! Masih baru ini.

2. Ambilah sudah ini Bu! Setengah harga saja.

Kalimat nomor 1 merupakan kalimat imperatif yang sering digunakan oleh pelaku usaha 
480 Sosialisasi Penggunaan Kalimat Imperatif Sebagai Strategi Pemasaran UMKM pada Masa Pandemi Covid-19 Di Desa Pejeng Gianyar-Dewa Ayu Kadek Claria

DOI: https://doi.org/10.31004/abdidas.v2i3.300

untuk menarik perhatian pembeli. Dengan menyatakan suruhan kepada pembeli untuk melihat produknya, kalimat ini juga sekaligus mengandung makna bahwa barang yang ditawarkan merupakan produk terbaru dan memiliki kualitas yang bagus sehingga pelaku usaha berani menyarankan atau menyuruh pembeli untuk melihat dagangannya secara lebih mendetail. Kalimat nomor 2 terjadi saat seorang pedagang dengan konsumen beradu argumen terkait masalah harga sehingga untuk menawarkan barangnya, pelaku usaha tidak segan-segan memberikan atau menyuruh pembeli untuk mengambil dagangannya seharga setengah dari hari normal. Kalimat imperatif suruhan ini juga sering digunakan oleh pelaku UMKM sebagai teknik mereka dalam memasarkan dan menawarkan produk yang dimiliki.

\section{e. Kalimat Imperatif Ajakan}

Kalimat imperatif ajakan merupakan kalimat imperatif dengan tujuan mengajak seseorang untuk melakukan sesuatu secara bersama-sama. Dalam hal ini umumnya penutur menginginkan seseorang atau lawan tutur untuk melakukan sesuatu bersama sehingga adanya kerjasama yang baik diantara keduanya. Rahardi (2005: 82) dalam kalimat imperatif ajakan, penanda kalimat yang paling banyak dan sering ditemukan digunakan adalah kata ayo dan mari. Kadar perintah dari kalimat ini juga masih dalam bentuk yang halus dan sopan dengan adanya penggunaan penanda kesantunan ayo dan mari. Kalimat imperatif ajakan juga ditemukan digunakan dalam pemasaran produk UMKM oleh pelaku usaha di Desa Pejeng terhadap konsumen yang mana kalimat imperatif ajakan tersebut dapat dilihat sebagai berikut;

1. Ayo kita sama - sama buktikan! Baju ini muat di saya yang besar ini kok, apalagi dipakai $\mathrm{Bu}$ Gek yang langsing ini dijamin cantik jadinya.

2. Mari saya antar ke Pengrajinnya Bu! Kalau di pengrajin bisa ambil grosiran jadi dapat harga lebih murah.

Kalimat nomor 1 merupakan kalimat imperatif ajakan yang digunakan oleh seorang pedagang kain dan baju di pasar di Desa Pejeng yang mana penutur menyarankan mitra tutur yang merupakan konsumennya untuk mencoba baju yang sedang dipilih. Kalimat juga dilengkapi dengan pujian sehingga meningkatkan minat konsumen untuk membeli baju tersebut. Kalimat nomor 2 juga merupakan kalimat imperatif ajakan dalam bentuk yang halus yang mana dalam kasus ini pelaku usaha menawarkan langsung kepada konsumen untuk di antar ke pusat pembuatan souvenir atau pengrajinnya langsung secara bersama-sama untuk memperoleh harga yang lebih murah apabila melakukan pembelanjaan secara grosir.

Setelah diadakannya sosialisasi terkait penggunaan kalimat imperatif kepada para pelaku UMKM terdapat peningkatan dalam kemampuan yang dimiliki para pelaku usaha dalam menggunakan kalimat imperatif untuk memasarkan produk mereka. Hal tersebut dapat diketahui dari hasil evaluasi berupa wawancara akhir yang dilakukan yang mana para pelaku usaha akhrinya mampu memilih dari kelima kalimat imperatif yang ada, mereka mampu menggunakan 
481 Sosialisasi Penggunaan Kalimat Imperatif Sebagai Strategi Pemasaran UMKM pada Masa Pandemi Covid-19 Di Desa Pejeng Gianyar-Dewa Ayu Kadek Claria

DOI: https://doi.org/10.31004/abdidas.v2i3.300

atau memilih kalimat imperatif yang tepat dan menyesuaikan dengan kondisi yang dibutuhkan. Dalam wawancara, pelaku usaha juga menyatakan adanya peningkatan penjualan produk dengan menggunakan kalimat-kalimat imperatif dengan mempertahankan kesantunan yang ada yang digunakan pada konsumen. Hasil evaluasi menunjukkan kegiatan pengabdian yand dilakukan dalam bentuk sosialisasi ini berjalan sesuai dengan yang diharapkan dan mampu menjadi solusi bagi para pelaku UMKM.

\section{SIMPULAN}

Kalimat imperatif merupakan kalimat perintah yang memiliki fungsi untuk mengarahkan seseorang melakukan sesuatu. Berdasarkan hasil pengabdian kepada masyarakat dalam bentuk sosialisasi dengan menerapkan lima jenis kalimat imperatif dalam pemasaran yang dapat digunakan oleh pelaku UMKM di Desa Pejeng, Kecamatan Tampaksiring, Kabupaten Gianyar, Provinsi Bali, dapat dikatakan sosialisasi berjalan dengan baik dilihat dari peningkatan kemampuan para pelaku usaha atau UMKM dalam menggunakan dan memilih kalimat imperatif yang tepat dalam menawarkan produk yang dimiliki. Kelima jenis kalimat imperatif tersebut terdiri dari kalimat imperatif biasa, kalimat imperatif pemberian izin, kalimat imperatif permintaan, kalimat imperatif suruhan dan kalimat imperatif ajakan.

Variasi penggunaan kalimat imperatif yang digunakan oleh pelaku UMKM di Desa Pejeng sudahlah sangat baik, hanya saja hal tersebut perlu dikombinasikan dengan penggunaan kalimat persuasif sehingga akan lebih memaksimalkan strategi yang telah digunakan sebelumnya. Bentuk promosi yang sejauh ini bersifat konvesional atau personal selling perlu dikembangkan dan ditingkatkan dengan mengenalkan pemasaran dalam bentuk online yang dapat dilakukan secara gratis sehingga tidak membebani para pelaku usaha yang baru merintis.

\section{UCAPAN TERIMAKASIH}

Penulis mengucapkan terima kasih kepada Lembaga Pengabdian Masyarakat (LPM) Universitas Warmadewa karena telah memfasilitasi pelaksanaan pengabdian ini. Penulis juga mengucapkan terima kasih kepada segenap masyarakat Desa Pejeng Kecamatan Tampaksiring, Kabupaten Gianyar, Provinsi Bali yang terlibat dalam kegiatan sosialisasi.

\section{DAFTAR PUSTAKA}

Chaer, A. (2015). Sintaksis Bahasa Indonesia: Pendekatan Proses. Rineka Cipta.

Claria, D.A.K \& Sariani, N. . (2020). Metode Komunikasi Persuasif untuk Meningkatkan Motivasi Berwirausaha Masyarakat di Desa Kesiman Kertalangu pada Masa Pandemi Covid-19.

https://www.ejournal.warmadewa.ac.id/index .php/licosjournal/article/view/2281

Darmawanti, A.A.S, Indriani, M, S \& Astika, M. (2020). Analisis kalimat imperative dalam Video Tutorial Skincare Clarin Hayes di Youtube dan Relevansinya pada pembelajaran Teks Prosedur di SMA. Jurnal Pendidikan Bahasa Dan Sastra Indonesia Undiksha, 9(2), 324-333.

Hermawan, A. (2012). Komunikasi Pemasaran. Erlangga.

Hodairiyah. (2019). Bentuk-bentuk kalimat imperatif permintaan pada iklan rokok Djarum 76. Leksema Jurnal Bahasa Dan Sastra, 4(1), 11-20. 
482 Sosialisasi Penggunaan Kalimat Imperatif Sebagai Strategi Pemasaran UMKM pada Masa Pandemi Covid-19 Di Desa Pejeng Gianyar- Dewa Ayu Kadek Claria

DOI: https://doi.org/10.31004/abdidas.v2i3.300

Kasmilawati, Isna \& Agustina, L. (2019). Kalimat imperative dalam Bahasa Lisan Masyarakat Dayak Deah. Stilistika: Jurnal Bahasa, Sastra Dan Pengajarannya, 4(2), 2019.

Kotler, Philip \& Amstrong, G. (1997). DasarDasar Pemasaran. Alih Bahasa Drs. Alexander Sandro. Prehelindo.

Pitana, I. G. (2009). Pengantar Ilmu Pariwisata. Andi.

Rahardi, K. (2005). Pragmatik Kesantunan Imperatif Bahasa Indonesia. Erlangga.

Sutisna. (2001). Perilaku Konsumen dan Komunikasi Pemasaran. Rosda. 